\title{
The FOMC in 1986: Flexible Policy for Uncertain Times
}

\author{
Philip A. Nuetzel
}

$\mathbf{T}$ economic growth and moderate inflation. The income selocity of money, defined as the ratio of nominal GNP to the narrowly defined money supply $\mathrm{M} 1$, declined even more apidly in 1986 than it had in the previous year.' Interest rates declined on balance over 1986, and the Federal Open Market Committee (hereafter" "Commitee" or "FOMC") viewed their decline and the associated rapid growth of $\mathrm{M} 1$ as a desirable development in light of the sluggish economy. As the year progressed, the Committee deemphasized M1 as a guide to policy while focusing on the broader monetary aggregates, $\mathrm{M} 2$ and $\mathrm{M} 3$, and several indicators of economic and financial conditions. In the uncertain economic environment that prevailed in 1986, the Committee was flexible in its approach to monetary policy.

This article reviews the FOMC's monetary policy decisions during 1986. The Committee's annual growth objectives for the monetary aggregates are discussed in the nex section, and the target ranges for 1986 are compared with actual money growth during

Philp A. Nuetzel is an economist at the Federal Resene Bank of St. Lous. Laura A. Prives provided research assistance.

NOTE: Citations referred to as "Record" are to the "Record of Policy Actions of the Federal Open Market Committee" found in various issues of the Federal Reserve Bulletin. Citations relerred to as "Report are to the "Monetary Policy Report to Congress," also tound in various issues of the Fecieral Reserve Bulletin.

M1 growth from $V / 1985$ to IV/ 1986 was 15.3 percent, up from 12.1 percent over the preceding four quarters. Over the same wo petiods, nominal GNP grew at rates of 4.2 percent and 6.3 percent, respectively. the year. Then, the Committee's views concerning the rapid growth of $\mathrm{M} 1$ are considered in more detail, and other variables that had a significant infuence on policy are discussed. Finally, the short-run directives issued by the FOMC during 1986 are reviewed chronologically.

\section{ANNUAL TARGETS FOR 1986}

Each Febmary, the Board of Govemors appears before Congress to report on the annual growth targets that the FOMC has established for the monetary and credit aggregates for the coming year. In July, the Board reports on the progress made toward meeting these goals and announces the FOMC's provisional growth largets for the following calendar year. The Commitee states its annual targets in terms of growth ranges from the fourth quarter of the previous year to the fourth quarter of the current year. The dates of the three meetings at which the annual target ranges for 1986 were considered are listed in table 1 along with the ranges established for $\mathrm{M1}, \mathrm{M} 2$ and $\mathrm{M} 3$, and the actual growth rates of these aggregates during 1986 .

\footnotetext{
2These reports are required under the Full Employment and Balanced Growth Aci of 1978, also known as the Humphrey-Hawkins Act.

The Committee's use of the fourth quarter of the previous year as the base period for estabilishing the current year's growth targets leads to an upward drift in money growth if the growth of an aggregate during the previous year exceeded the target range for that year. The "base drift" problem is discussed by Broaddus and Goodiriend (1984). For a viewpoint that favors base dritt, see Walsh (1986).
} 


\section{July 1985 Meeting}

The tentative ranges for 1986 established at the July 1985 FOMC meeting reflected the Committee's feeling, at that time, that continuation of the rapid money growth in the first half of 1985 might be inconsistent with sustainable economic expansion and reasonable price stability. The tentative 1986 range for $M 1$ of 4 to 7 percent was 2 percentage points narrower than the 3 to 8 percent rebased range adopted in July 1985 for the II/1985-IV/1985 period, ; the upper limit of the tentative M3 range of 6 to 9 percent was one-half percentage point lower than the upper limit of its 1985 range.

The growth of the three monetary aggregates slowed somewhat during the second half of 1985. M1 growth exceeded the upper limit of its rebased range, however, and its velocity declined even more sharply than it had during the first half.

\section{February 1986 Meeting}

The annual growth ranges for 1986 were reconsidered at the Committee's meeting on February 11-12, 1986. For M1 growth, the Committee chose a target range of 3 to 8 percent, which was based on expectations that M1 growth would slow while nominal GNP growth would accelerate. This range was 2 percentage points wider than the FOMC had tentatively planned, reflecting continuing uncertainty about the future behavior of M1 and its velocity. The Board's report to Congress stated that:

The width of the M1 range reflects contimuing uncertainty about the behavior of M1 under varying economic and financial circumstances.... While the range for $\mathrm{M} 1$ is wide enough to allow for some variation in behavior of the aggregate's income velocity in response to changing conditions, the mange was set on the assumption that there would not be a large drop in velocity, such as occurred in 1985 . In that connection, the Committee will evaluate behavior of M1 in light of its consistency with other monetary aggregates, economic and financial developments, and the potential for inflationary pressures. ${ }^{\overline{5}}$

The 6 to 9 percent ranges for $\mathrm{M} 2$ and $\mathrm{M} 3$ established tentatively in July were affirmed by the Committee at

${ }^{\triangleleft} B$ ecause of the apparent decline in $M \uparrow$ velocity during the first half of 1985 , the FOMC decided in July $\$ 985$ that the annual range originally established for M1 growth was undesirable. The Committee voted to move the base period of that range from N/1984 to lt/1985. See Hafer (1986) for a discussion of the decision to rebase the $M$ range and the influence that dectining $M 1$ velocity had on the FOMC's decisions in general during 1985.

SReport (April 1986), p. 214.

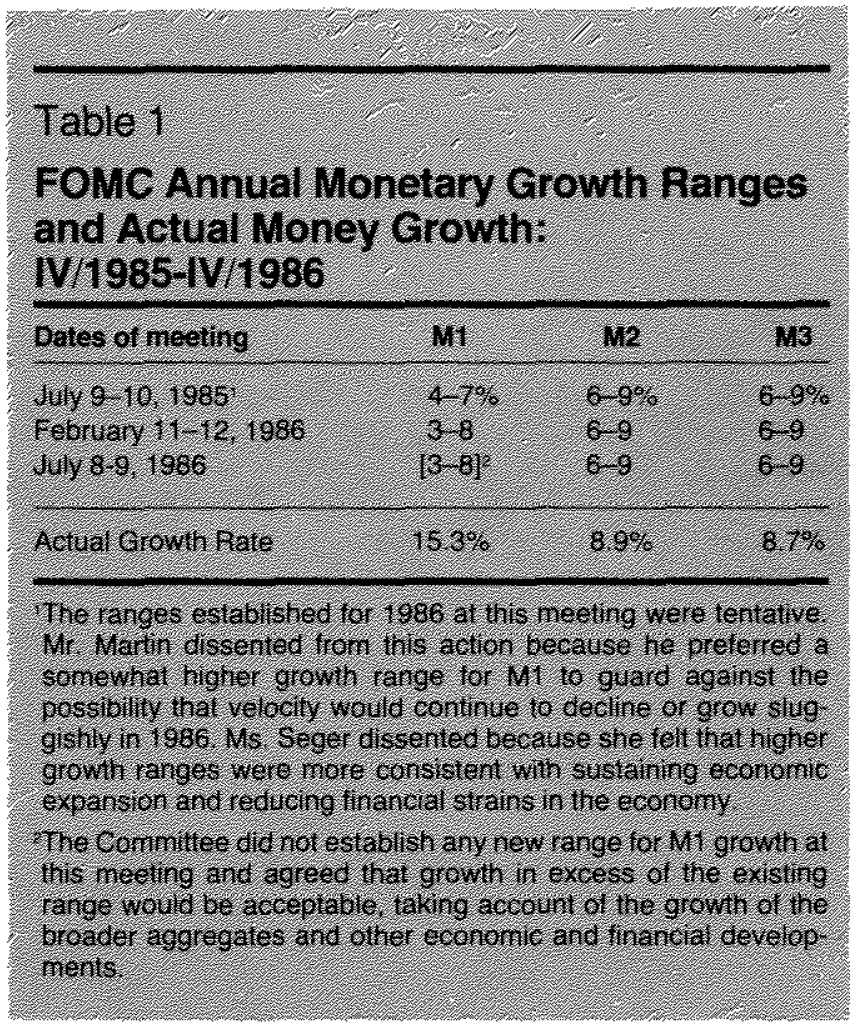

the February meeting. The growth of these broader aggregates had been within their target ranges in 1985, and it was observed that "on balance over the past few years, the behavior of $\mathrm{M} 2$ and $\mathrm{M} 3$ seemed to have been less affected by institutional and interest rate changes." "6

\section{July 1986 Meeting}

Over the first half of 1986 , the growth rates of $\mathrm{M} 2$ and M3 were roughly in the middle of their target ranges. M1 growth slowed in the first quarter from its pace in 1985, but accelerated sharply in the second quarter, leaving its annualized growth rate from December through June at 13.3 percent, more than 5 percentage points above the upper bound of the Committee's target range for the year. Other evidence reviewed by the Committee at the meeting of July 8-9, 1986, suggested that the rate of economic growth had slowed considerably in the second quarter from the $2.9 \mathrm{per}$ cent growth of real GNP registered in $\mathrm{I} / 1986$. Further- $^{7}$

sRecord (June 1986), p. 410. The Committee also adopled a monitoring range for the growth of total domestic nonfinancial debt of 8 to 11 percent.

7 Revisions showed that real GNP grew at a rate of 3.8 percent in $1 / 1986$ and 0.6 percent in 1//3986. All of the data used in the text in discussing the Committee's deliberations are those that were available to the committee at the time. 
more, wage and price increases continued to moderate over the first half of the year, even when the direct effects of declines in food and energy prices were eliminated.

The Committee reaffirmed the long-run growth ranges of 6 to 9 percent for $M 2$ and $M 3$. In their discussion of the range for M1 growth, however, the members again emphasized uncertainties affecting the outlook for M1 velocity and the changes in M1's composition resulting from the rapid growth of its deregulated, interest-bearing component. Interest rates had declined by 1 to 2 percentage points during the first half and were thought to be associated with the rapid growth of M1. Some members thought that the $M 1$ range should be eliminated, "at least pending the reestablishment of a more predictable relationship with overall measures of economic activity." $A$ majority, however, preferred to retain a range for M1 "even though they believed its operational significance could only be judged in the perspective of concurrent economic and financial developments, in cluding the behavior of $\mathrm{M} 2$ and $\mathrm{M} 3{ }^{\text {"s }}$ Rather than raising or rebasing the existing $\mathrm{M} 1$ range, the Committee acknowledged its desire to accommodate uncertain changes in M1 demand by agreeing that, affer accounting for the behavior of the broader aggregates and other developments, including trends in interest rates, growth of M1 in excess of 8 percent would be acceptable for 1986 .

\section{Actual Monev Growth in 1986}

The actual growth rates of the monetary aggregates for 1986 are reported at the bottom of table 1 . M1 growth of 15.3 percent was 7.3 percentage points above the upper bound of its range set early in the year. This growth rate represents a significant acceleration from the already rapid 12.1 percent growth of $M 1$. from $W / 1984$ to $W / 1985$. In comparison, M1's average annual growth rate over the 1960-84 period was only 5.8 percent.

One reason why the Committee accepted the rapid M1 growth during 1986 was that the growth rates of M2 and M3 were quite close to the 9 percent upper limit of their target ranges for the year. $\mathrm{M} 2$ growth of 8.9 percent and M3 growth of 8.7 percent were slightly more rapid than their respective growth rates of 8.7

${ }^{8}$ Record (October 1986), p. 708.

sibid. percent and 7.7 percent over the IV/1984-IV/1985 pe riod. The Committee felt, however, that the behaviof of these aggregates was generally consistent with its overall policy objectives. The Board's mid-year report to Congress stated that "during a period of greater overall price stability and adequate capacity relative to the demands placed upon it:" monetary policy had been able "to accommodate demands for money and credit, helping facilitate further declines in interest rates...."

\section{THE FOMC'S GUIDES FOR POLICY IMPLEMENTATION}

The Committee's use of a variable as a policy guide is based on assumptions about the effect of that variable on real economic growth and the rate of inflation, which are of ultimate concern, as well as the ability of policy actions to influence that variable. As noted previously, the deemphasis of M1 as a policy guide was a reaction to the instability of M1 velocity. In this section, we review the Committee's explanation for the unusually rapid growth of $\mathrm{M} 1$ relative to nominal GNP and its reasons for believing that the relationship between M1 and economic activity would be subject to a high degree of uncertainty for some time. We then discuss the Committee's reasons for continuing to use other variables as policy guides, such as M2 and M3, the level of interest rates, the foreign exchange value of the dollar, real GNP and indicators of output and prices.

\section{Institutional Changes and M1}

In accounting for the rapid growth of $\mathrm{M1}$ in 1986, the Committee emphasized that the composition of $\mathrm{M} 1$ had changed in part because of the deregulation of deposit interest rates and minimum balance requirements that had taken place under the Monetary Control Act of 1980 and the Garn-St. Germain Act of 1982." From 1980 to 1985, for example, the proportion of interest-bearing checkable deposits lother checkable deposits, or OCDs) in M1 rose from 5.5 percent to 27.6 percent, a trend that continued in 1986.

Table 2 shows the annualized growth rates of $\mathrm{M} 1$ and its three major components for each quarter of

\footnotetext{
${ }^{t 0}$ Report (September 1986), p. 603.

"For a discussion of federal policy on deposit interest rate ceilings, or Reguation $Q$, and the phaseout of deposit regulation, see Gibert (1986).
} 


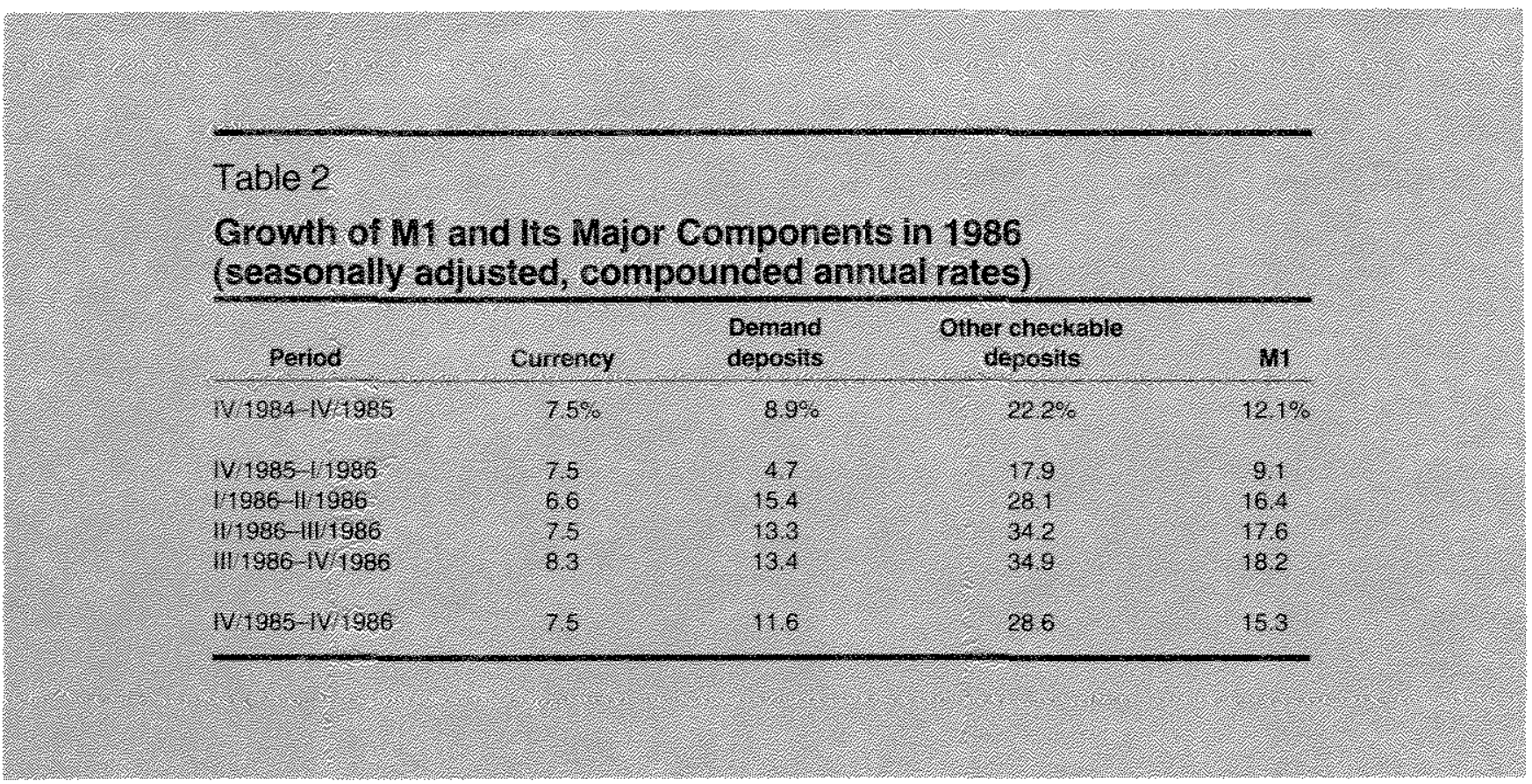

1986 and for the year as a whole. The OCD component of M1 grew at 28.6 percent, 6.4 percentage points faster than its 1985 growth rate. Growth in demand deposits was also quite rapid, accelerating from 8.9 percent in 1985 to 11.6 percent in 1986. Growth of the public's currency holdings was unchanged at 7.5 percent.

The Committee attributed much of the rapid growth of OCDs and demand deposits, and hence declining $M 1$ velocity in 1986, to declining interest rates and subsiding inflationary expectations. In the midyear report to Congress, the Board stressed that "the advent and expansion of interestwearing checking accounts over the years have attracted more savings-type balances and have increased the responsiveness of M1 to interest rate changes." "Commenting on the rapid growth of demand deposis, Chairman paul Volcker said that there were "some indications of a greater willingness of businesses to hold demand deposits a a time of lower interest rates, party because, with interest rates down, a larger balance is necessary to compensate banks for a given amount of services,"

Chart 1 shows the paths of selected short-1erm

IReport (September 1986) 0. 614. Suppor for the view that the interest elesticity of money demand has increased with deposit deregulation can be lound in Keeley and Zimmerman ( 1986 ), Roth (1985), Mehra (1985) and Wenninger (1986).

: volcker (1986), p. 640 .
Interest rates and the growth of M1 over 1985 and 1986 . There were major accelerations in M1 growth accompanied by declining short-term rates during the spring of 1985 , the late winter and spring of 1986, and the summer of 1986 . On the ather hand, there were also accelerations of $\mathrm{M} 1$ growth during periods of relatively stable interest rates in the summer and the late fall of 1985, and the fall of 1986 . The consensus at the Committee's meeting in July 1986 was that rapid M1 growth during the first half of the year reflected. lagged adjustments to decining intlationary expectations and interest rates; it did not seem to hold the usual potential for reigniting inflationary pressures when judged in the context of other developments, including more restrained growth of the broader aggregates. ${ }^{\mathrm{i}}$

While the Committee thought that M1 still had some informational value, it did not wish to restrain the process of adjustment that it felt was responsible for rapid M1 growth and declining velocity. Chatman volcker stated in July 1986 that ". . . a firm conclusion concerning the nature and stability of future velocity characteristics may take years of experience in the new institutional and economic setting.",35 The Chairman went on to summarize the Committee's attitude toward the use of M1 as a policy tool:

\footnotetext{
"See the Pecord (October 1986 ), p. 708.

15Volkker (1986), p. 641.
} 
Cher: :

\section{Short-Term Interest Rates and MI Growh}

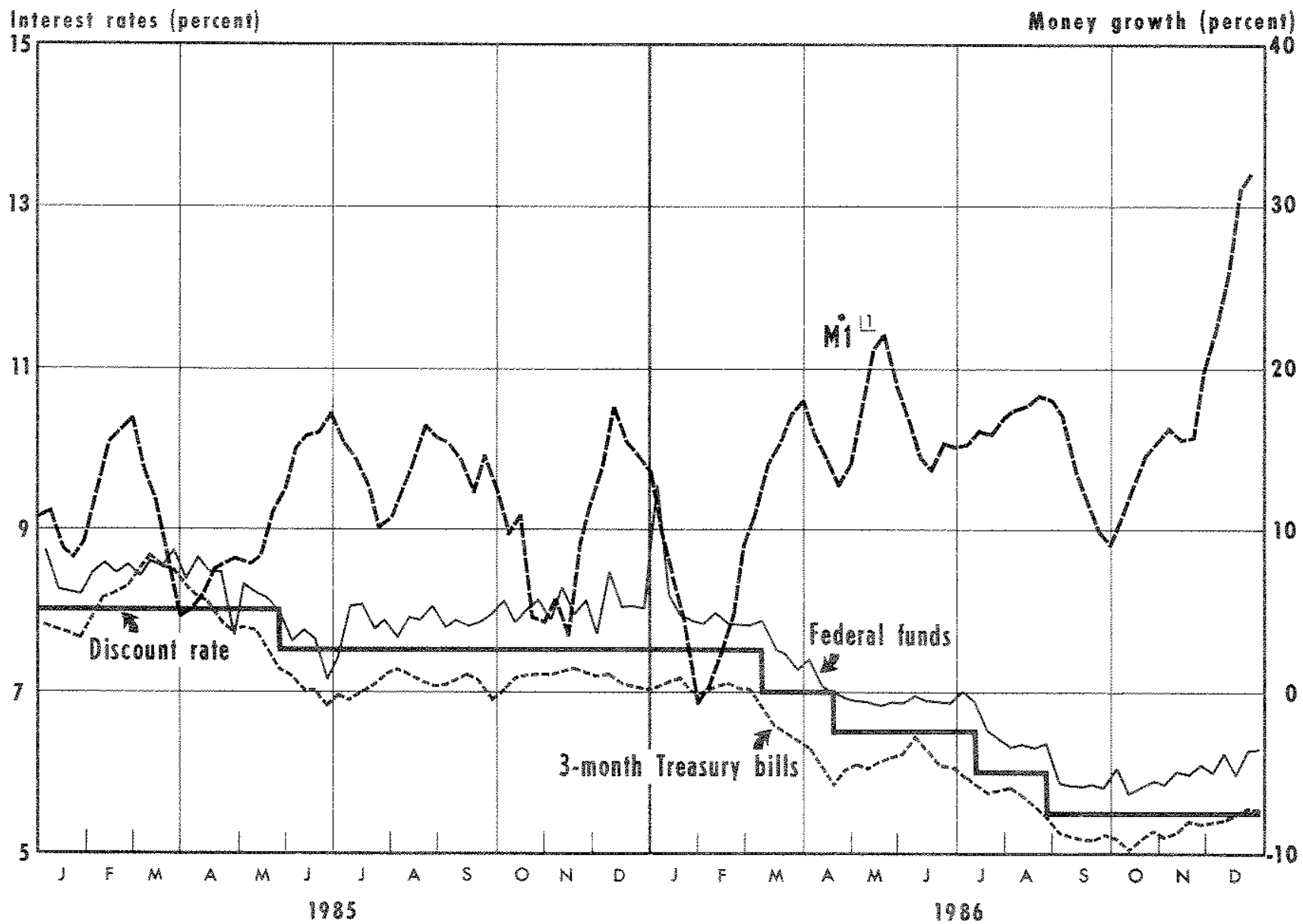

1 Ml growth rates are compounded annual rates of change of touf-week moving overoges of Ml from four weeks previous.

Experience over the fret half of 1986 undersconed the difficulty - I would say impossibility - of conducing monetary policy in current circumstances according to one or two simple, presel criteria ... The weight of the evidence strongly suggests that Milone during this period of economic and institutional transition is not today a reliable measure of future price pressures tor indeed sood short-term "leading indicator" of business activityl. The more restrained perfomance of the broader aggregates, as well as the performance of the economy and prices themselves, point in a different direction.

\section{M2 and M3}

In recent years, the velocity behavior of $\mathrm{M} 2$ and $\mathrm{M} 3$

relbid, 0. 642 . have not changed as radically as M1's. Apparently, the shifts in asset holdings resulting from the combination of falling interest rates and deposit deregulation have occurred largely within the broader aggregates and have not led to as large a surge in their growth as in M1's.

The FoMC has responded by assigning more weight to $\mathrm{M} 2$ and $\mathrm{M} 3$ as policy guides ${ }^{13}$ In 1986 , the Commit-

7 Monetary policy actions have a weaker infuence on the broader aggregates than on Mi, however, because most of the non-M1 deposil liablittes included in $M 2$ and $M 3$ are not subject to reserve requirements. Moreover, infomation on these aggregates is avatuable at a longer lag. See Lawler (1981). Also, Hafer (1981) presents empincal evidence suggesting that $\mathrm{M} 2$ is less controllable through policy actions than Mt. 


\section{Organization of the Commitfee in 1986}

The ledrtal Upen Market conmmee vionic

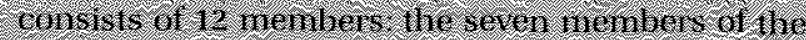
lederal Reserve beard of Governors and five of the 12. hederal Reserve Bank presifents the chaman

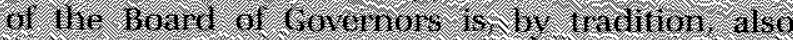
Gratman of the cominitee. The mestident of the

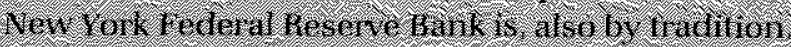
Is Vice thaiman All fecteral heserve Bank prest dents attent Conmitre meetings and pesen heir views hut only those th tro are nimbers of the Cominitee may vote foln nemberships rotate

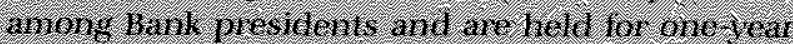
tems heginning an Mared 1 of eheh vear the

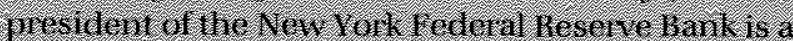
peimanent toting menber of the Committee

Menhers of lie Board of Luemins at the liegin: ins of 1986 melined chaman paul I voleker.

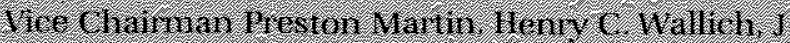

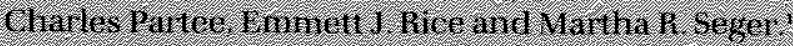
The tem of I Chafles partee exphud on relinany 1 The Mo spen seats on the Board were film ty

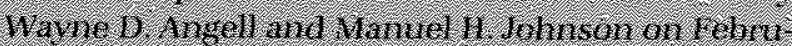
ay.7. Pieslon Nartin tesigned from the Board effer.

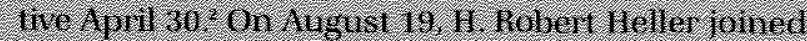

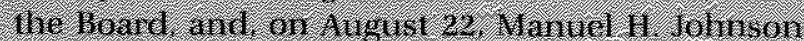
took the office of tice dhaumin Hentv C. Wallich

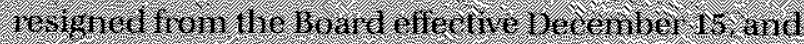

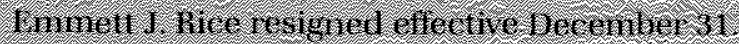

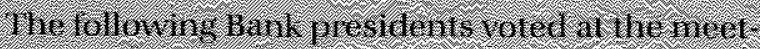
ing on rebinary 11 and 12 , 1986 . mober $\mathrm{p}$. Blach

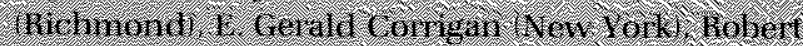

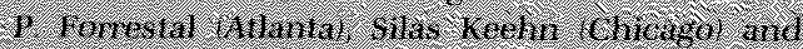

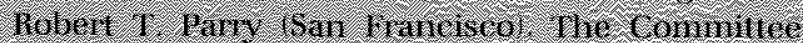
membership changed in Marth and he presidents:

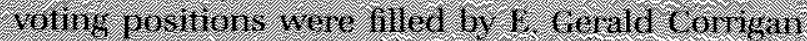
New vohk loger Guifey ikansas cilve Karen N

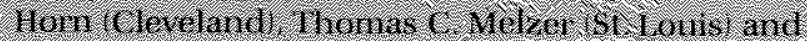
Trank I Momis Moston:

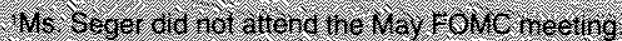

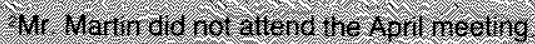

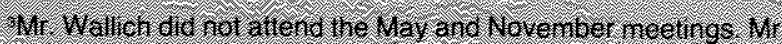

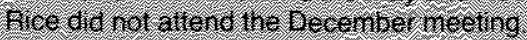

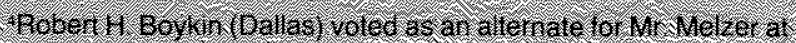
Ite Nay neeing
The conninite met eight inies at regular scheduled neetings dirng 1986 io dischiss efe. homic trends and io decide upon the fintre course of opei-market opetalions: As in previous vears: telephone on telegtam em sultations were held oc-

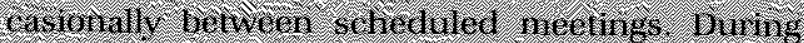
each regulary schedifted meeting a divective was isstied lo the hedend heserve Rank of New tomk tareh directive comtained t short review of eto. nomic deretopments, the senetal ecomomic sonis sought by the committec, the Committees long

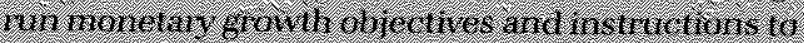
the Wanager of the System topen Market Aecoum at the New tord Bunk for the eonduct of open-matket optrations These instintions typically were stated in terms of the degree or pressume on reseive: positions. The tatler were assoctated with expertad. show-term browil tales for M1. M2 and MI3 Itat were in thin consiffered to be consistent with hesmad longer thin gronth tates of the monetary dy: Gegates t The ramini lee also specified intermeet ing tanges for the terteral funds rate. These ranges pravide a mechanish for iniming eonsultations between meetings whenever it appears that hie constraint of the rederal funds fate is proving in: consistent with hie objectnes for he behtwor of

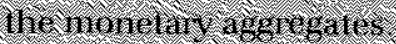

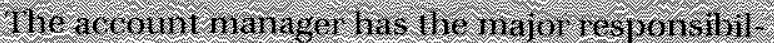
if for tornulating plans regarding the limins t tpes

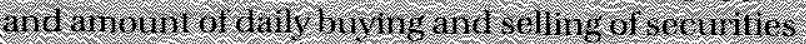

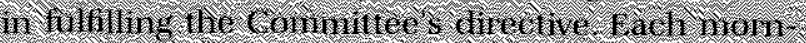

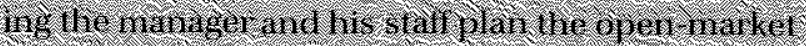
operainns for hiat day Wiis plan is developed on line basis ol the Commitree s directive and the latest develoyments alterting nomev anit rotedit maiket conditions the growth af the nenetar angregates aid bank resine condituons. The ninagen also

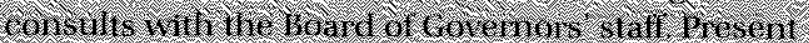
minket conditions and oper-market operations That the manager proposes 10 escevile are tis.

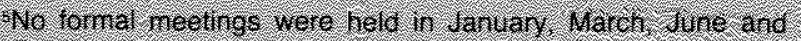
oteloher

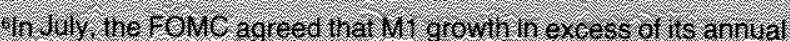
targer rarge Would be ace eprabie ard disconinued st i renents

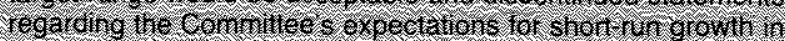
14: 


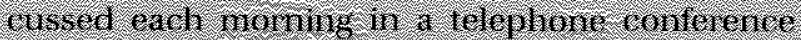

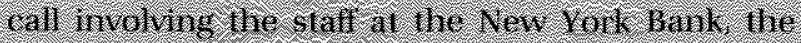

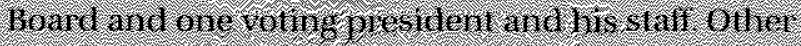

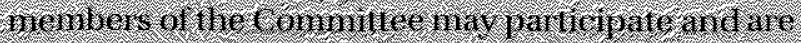

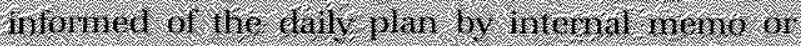
the

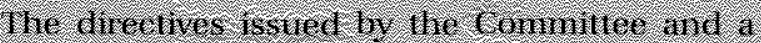

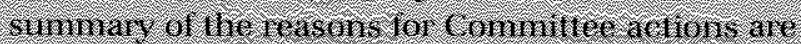

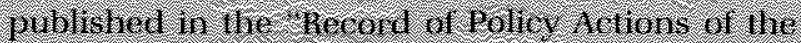

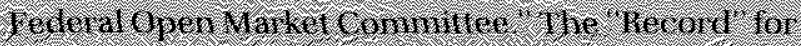

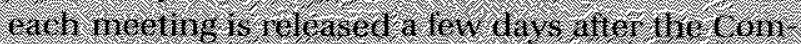

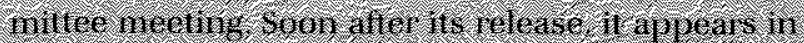

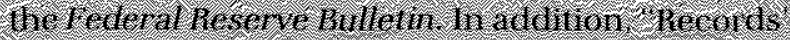

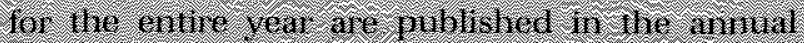

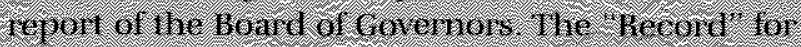

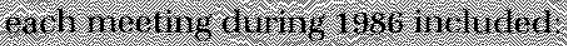

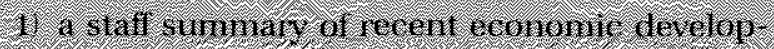

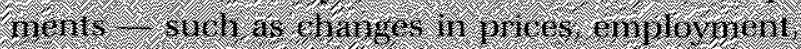

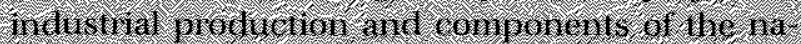

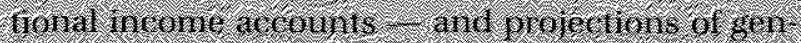

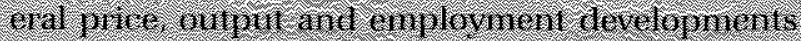

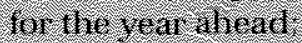

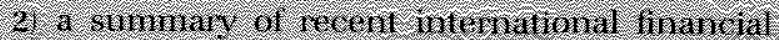

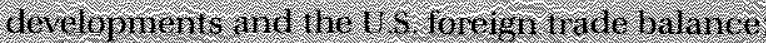

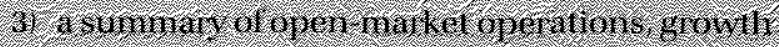

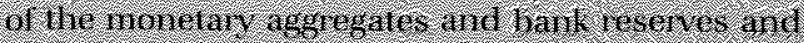

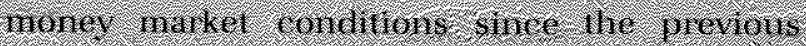
Tiestivg

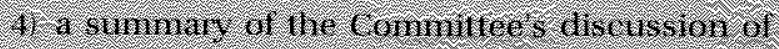

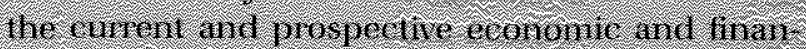

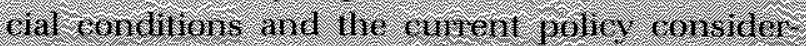

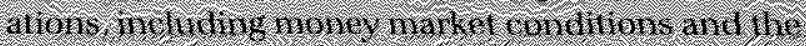

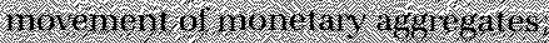

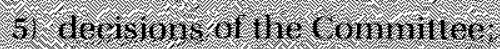

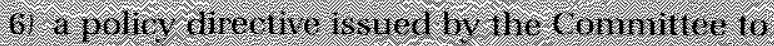

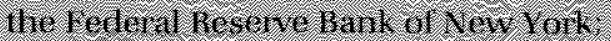

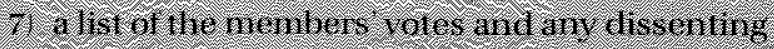
conthrems

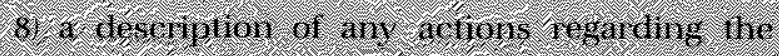

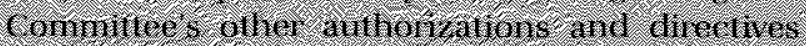

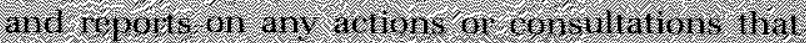

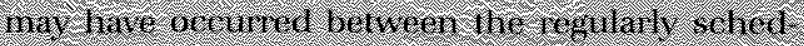

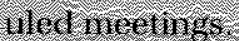

tee often evaluated potential changes in policy on the basis of the recent growth of these aggregates, among other factors. For example, in April, the Committee viewed the growth of M2 and M3 at rates within their target ranges as evidence that the rapid growth of M1 did not represent an excessive buildup of liquidity ${ }^{78} \mathrm{At}$ later meetings, when $\mathrm{M} 2$ and $\mathrm{M} 3$ were near the upper limits of their ranges, members expressed more concern about the implications of accommodative policy for inflation..$^{19}$

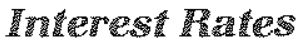

The Committee also evaluated potential changes in its policy stance during 1986 in the context of recent movements in interest rates. By implementing an accommodative policy in 1986, the Committee sought to provide the reserves necessary to support increases in money demand. ${ }^{20}$ At two meetings, though it felt that

\footnotetext{
${ }^{18}$ See the Record (September 1986), pp. 649-50.

${ }^{19}$ See the following Records: November 1986, pp. 784-85; January 1987, pp. 34-35; February 1987, pp. 120-21

${ }^{20}$ See Report (September 1986), pp. 612-13.
}

less restrictive reserve conditions were desimable, the Committee contemplated that the easing would be achieved through discount rate reductions by the Board. This was expected to facilitate a market tendency toward lower interest rates." Moreover, the appropriateness of potential intermeeting adjustments in the provision of reserves were viewed as conditional on near-term changes in rates, including potential discount rate reductions.

While it sought to promote easier credit market conditions, the Committee also took account of movements in long-term interest rates as indicators of changes in inflationary expectations. For example, an increase in interest rates before the september meeting, together with some other developments, was interpreted as a sign of an increase in expected inflation. This was one factor that led to a vote for "maintaining unchanged conditions of reserve avallability, "and one

2a See the following Records: Oclober 1986, p. 710 ; November 1986 ,
p. 784 . The same point is discussed in Record (June 1986), pp. $4 \neq 1-12$. 
nember believed that less ease in polcy implementation was desiable at that time. ${ }^{3 x}$

\section{International Developments}

Concems about the extemal sector also inthenced he FOMC's policy actons in 1986 . The foreign axchange value of the tollar had declined substantialy on a fade-weighted basis since eany 1983 . As a result, the trade deficit was expected to decine during 1986 . but it widened instead and was a continuing element of uncerainty in the economic outook. Throughout the yean, the commitee expressed doubts about the timing and magnitude of any improvement in the rade balance because it believed that foreign producers would atrempt to mamtain heir U.S. market shares by reducing their profit margins: 2 the Commin tee also felt that moreases in U. . net exports would be hindered by suggish growth in the economies of some maior US. Trading pariners in the absence of more stimulative policies abroad ${ }^{2-1}$

While the falling dollar improved the prospects for a smaller trade defin, Commitee members noted that it also had a potential inflationary impact ${ }^{23}$ Futhermone, the trade defoit impled large capital inflows from abroad that were chancing domestic economic activy. Loss of conflence in the dollar ming require shap increases in domestic interest res to maintain the infow of foreign capital members of the Commit fee ofter mentioned this risk to economic oxpansion ${ }^{3 .}$ In general, the Commita felt hat grater caution should be exercised in providing reserves in the event of shap dolar depreciation during intameeting pernods.

2See the Racord (January 1987), 0. 34.

zMann (1986) presents evidence in support of this view. See Report (Apri 1986), p. 216, Report (September 1986), 0. 610, and the following Records: fune 1986, p. 409; Juy 1986, p. 480; Jaruary 1987, p. 33.

${ }_{24} 4$ See Fepor (September 1986), po, $604-05$ and $p .610$, and the following Fecords: Juy 1986, op. 480-81; Cotober 1986, p. 707; January $1987,0.33$. Also see the Record in Press Rolease, Federai Resene Board of Governors, Febuary 13, 1987, $p .7$. There were. in lact, limited moves toward expansionary policies in some majo industrial nations during the year, inchuting coordinated rounds of discount rate reductions with the Federal Feserve.

25 See the following Records: June 1986, p. 409; November $1980, p$. 783-84; January 1987, po. 33-34; February 1987, p. 120.

26e se the hollowing Records: whe 1986, p. 412; Oclober 1986, p.710; November 1986, p. 784. Aiso, see Report (September 1986 ). p. $64 t$, for a brief discussion of the risks of shamp depreciation of the doliar on foreign exchange markets, and how those risks intuenced the Board's decisions on discount rate reductions.

${ }^{27}$ See the following Fecords: June 1986, p. 412, Ocober 1986, p. 710 ; November 1986, pp. 784 85; January 1987, p. 35; toss Release. February 13, $1987, \mathrm{p} .11$.

\section{Real Activity and Prices}

Finaly, the ROMC's decisions in 1986 were guided by avalable data on production, employment, wages and prices, and projections of economic activity based on recont developments. Consumer prices rose by only 1 il percent in 1986 , the lowest rate of infation by this measure stnce 1965. Steep decines in oil prices early in whe vear contributed to the low rate of inflaton, but wage and price pressures were otherwise quite moderate. Monthy data on production and employment and the growth of real GNP indicated, over much of the year, that the expansion was proceeding at a slower pace than the Commitee had anticipated. Throughout the year, the members generally anticipated more rapid real growth and infation in later quarters. Nevertheless, current indications of sluggish growh, moderate price pressures and downside risks in the economic outook weighed heavily in the Com mitteds decisions to mantan the accommodative stance of poliwy 'The Commitee's views on the desirability of intemeeting adjustments in policy implomentation also depended upon indications of the pace of economic growh and inflation, among other developments."

\section{SMORT-RUN POLICY OBJECTIVES}

The foMC meets eight times each year to review economic developments and discuss the statiss of policy and its mplementation. A each meeting, the Committee's decisions are summanzed in a directive issued to the Federal Resere Bank of New Vork. The dinective is then used by the Manager for Domestic Operations, System Open Market Account, to guide the day-to-day implementation of monotary policy hrough open-market operations during the intermeoting period.

Recent policy directives specify the Commitee's decision about the appropriate "degree of pressure on reseve positions" of depository institurions for the

\footnotetext{
2aPea GNP grew 2,1 percen over the W/F $985-$ W/4986 period. At the Febuary 1986 meeting, the norecasts of real GNP growth of the mombers of the Commitee and Federal Reserve Bank presidents hat a contral tendency of 3 to $3^{1 / 2}$ percent. See the Record (June 1986), $p$. 408. Af the Juty 1986 meeting, the forecasts for the year had a cental tendency of $21 / 2$ 10 3 percent. See the Record (October $1986), 0.705$.

2For example, see the tolowing Records: Une 1986, p. 41: Sep tember 1966, 650; October 1986, 0.710.

For example, see the following Records: Sune 1986, p. 412; July 1986, 0. 482; Septomber 1986, 0.650, February 1987, po. 120-21; Press Felease, February $13,1987, p .11$.
} 


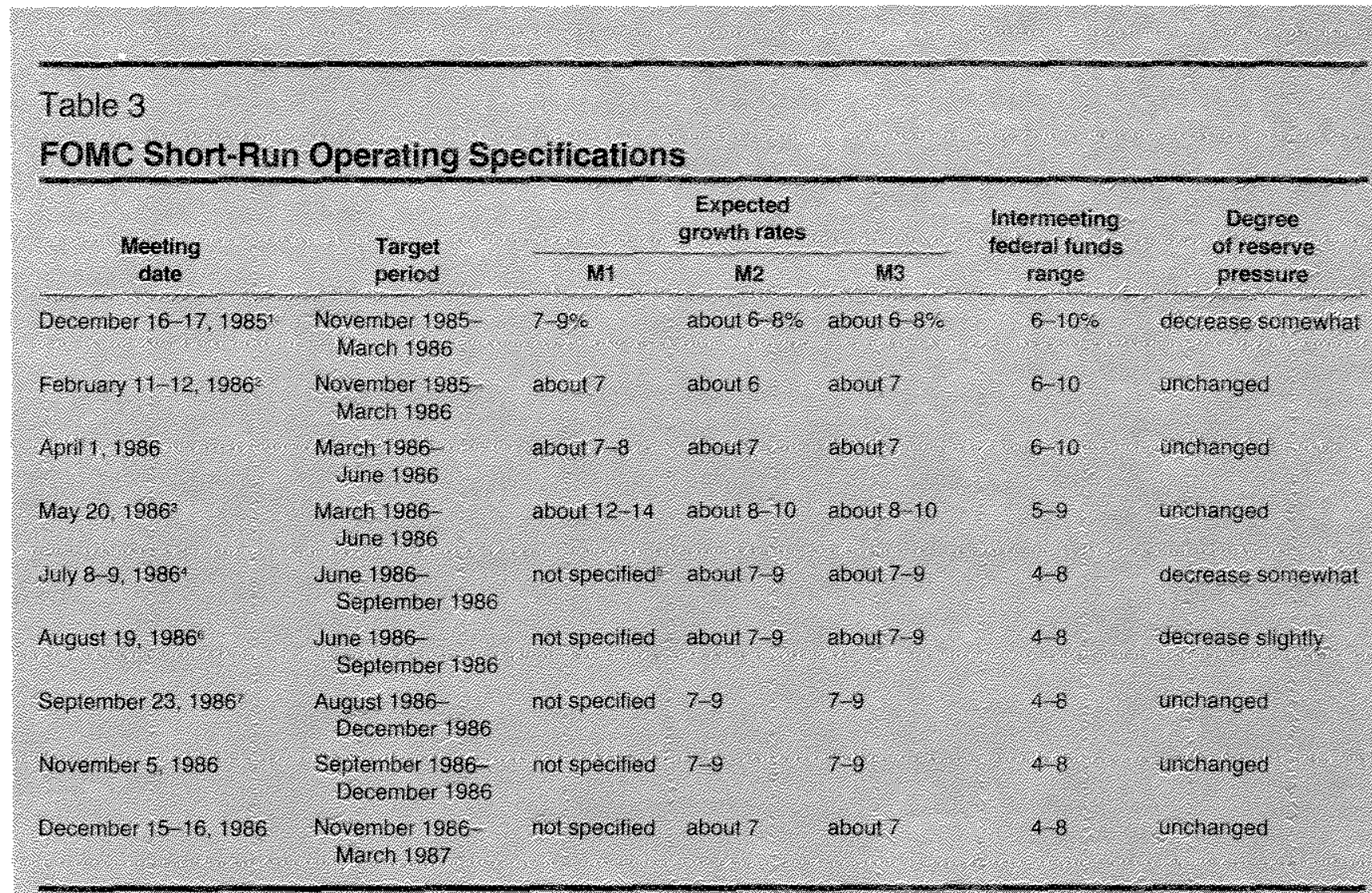

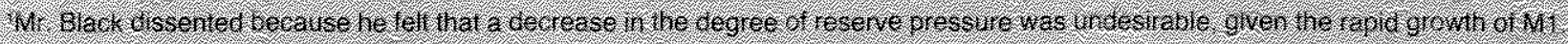

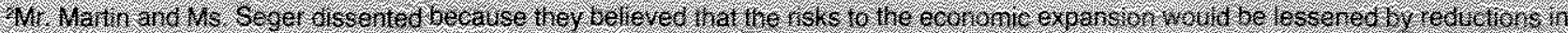

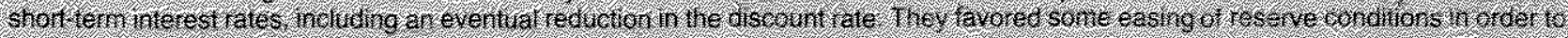
richltere theso redictions

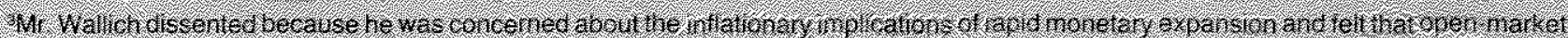

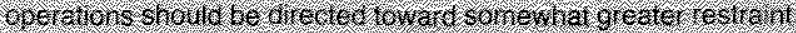

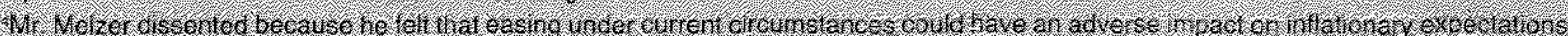

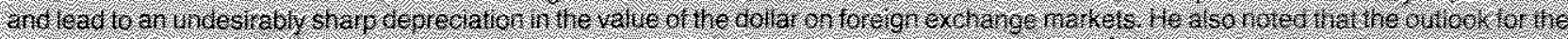

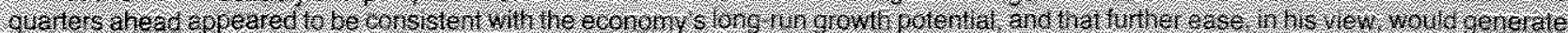

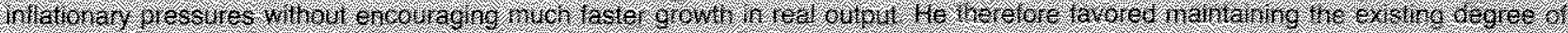
teserve. ressire

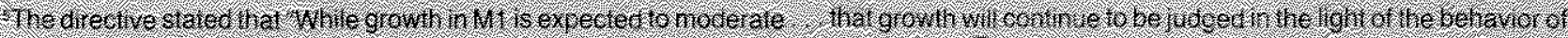

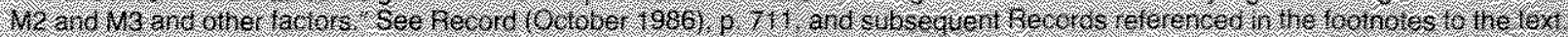

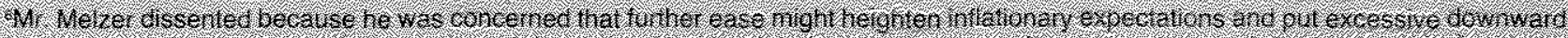

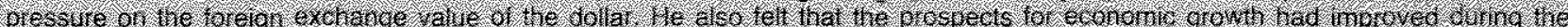

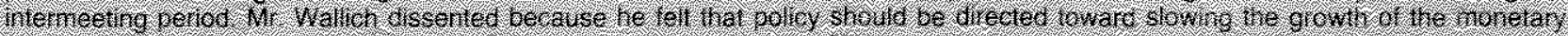

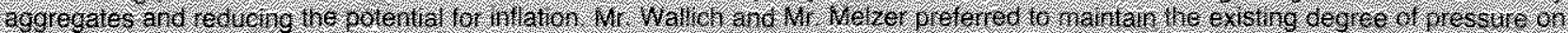

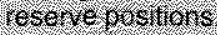

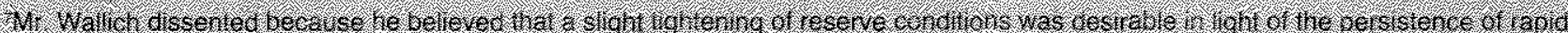

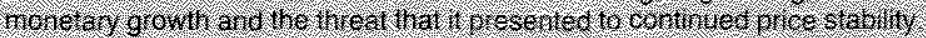

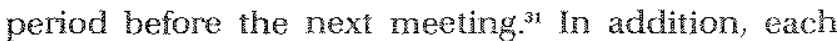
directive gives the Committee's expectation of the growth of various monetary aggregates for some shortrun target period, contingent upen the stated degree "See the direcives contained in any of the Pecords of Policy Actions
referenced below. of reserve pressure, and specifies an intermeeting range for the federal funds rate. If ieserve conditions proved to be inconsistent with a federal hunds rate in that range, the chamman could call for a Committee consultation before the date of the next meeting. Table 3 shows the Committee's expectations for money growth at each meeting in 1986 . The table also shows the intermeoting federal funds range established at 
each meeting and the degree of pressure to be applied to reserve positions.

\section{February Meeting}

The economic data reviewed at the February meeting indicated a moderate and, perhaps, improving rate of economic growth. Real GNP grew at an annual rate of 2.4 percent in IV/1985, which was slower than its 3 percent growth in the previous quarter. Several indicators of real activity, however, such as industrial production, housing starts and new orders for nondefense capital goods had shown strength in December after performing sluggishly in prior months. Moreover, substantial gains in employment were reported for January.

The Committee discussed a number of uncertainties that clouded the outlook at the February meeting. The sharp decline in oil prices in early 1986 was expected to have broadly favorable effects on the economy. These effects were difficult to assess, however, and energy-producing regions of the country and some oil-producing, developing countries with large debt burdens were likely to suffer. While prospective fiscal restraint associated with deficit reduction under the Gramm-Rudman-Hollings legislation was thought to have had a beneficial impact on financial markets, it was expected to have adverse effects on aggregate demand. Some members expressed concern over the strength of business investment in light of the uncertainties surrounding tax reform legislation, which was likely to tilt the composition of tax liabilities toward businesses and away from households.

Despite these considerations, members generally agreed that the economy was likely to grow at a faster rate during 1986 than it had in 1985. Some of the positive factors cited were the effects of rapid M1 growth, lower interest rates, higher stock prices and further declines in the foreign exchange value of the dollar. In fact, some members felt that inflationary pressures might crop up several quarters ahead.

The growth of M1 and M2 had slowed in the weeks prior to the February meeting, and money growth was close to the rate expected by the Committee in December for the November-to-March period. While that fact was encouraging, some members were concerned about the failure of short-term interest rates to decline further in recent months in response to the relatively accommodative stance of monetary policy that had prevailed for some time. There was general accord on the desirability of implementing policy "in a manner that would not in itself signal or encourage higher interest rates or impede the tendency for some market rates to decline." 32 There was, however, a perceived fisk of "a cumulating decline in the exchange rate that might discourage willingness to hold dollars at declining interest rates. In these circumstances, nearly all participants agreed that little or no change in reserve availability was warranted." 3

The Committee viewed its policy stance as accommodative, but some members felt that further easing might be necessary in light of the risks of a weakening economy. In fact, "the point was made that the discount rate might need to be reduced to permit or accommodate a market tendency toward lower interest rates and that such a move would be a desirable complement to open market operations...." ${ }^{34}$ On the other hand, members felt that the desirability of a reduction in the discount rate would depend on evolving circumstances and the prospects for similar action by major foreign central banks.

\section{April Meeting}

Interest rates of all maturities declined during the period between the February and April meetings, with long-term rates falling more sharply than short-term rates. The foreign exchange value of the dollar also declined on balance. At the time of the April meeting, however, there were conflicting signals about the pace of economic activity. Spending and real output were thought to have grown more rapidly during the first quarter than in the sluggish fourth quarter ${ }^{36}$ On the other hand, growth was clearly weak in some key sectors, and production and employment data for February were disappointing. On the bright side, declines in oil prices dominated the inflation outlook, and were viewed as instrumental in lowering inflationary expectations.

The Committee decided to maintain "about the existing degree of pressure on reserve conditions. ${ }^{\prime \prime 3}$ This was felt to be consistent with the long-run objec-

\footnotetext{
32Record (June 1986), pp. 411-12.

33/bid., p. 411.

\$4lbid.

${ }^{35}$ The Federal Reserve announced a reduction of the discount rate foron $71 / 2$ to 7 percent on March 7 . Subsequently, this action was matched by several foreign central banks.

36The Commerce Department had reported a dowtward revision in real GNP growth in IV/1985 to 0.7 percent.

${ }^{37}$ Record (July 1986), p. 482.
} 
tives for growth in the monetary aggregates. The growth of M1 had accelerated in February and March, and was near the upper end of the Committee's anmual range, but the growth of the broader aggregates had been moderate. The Committee discussed the possibility that demands for M1 balances could grow substantially if interest rates continued to decline. Furthermore, the velocity of $\mathrm{M} 1$ remained weak, and some members suggested that a more accommodative posture with respect to money and reserve growth might well become desirable. For the weeks immediately ahead, however, "most of the members felt that there should be no presumptions about the likely difection of any intermeeting adjustments."

The Board announced another reduction in the discount rate of one-half point, to $6^{1 / 2}$ percent, effective April 21. The Committee held a telephone conference on that date and agreed to make no changes in the current directive. Recent data indicated that growth in the monetary aggregates had accelerated, however, and the members felt that, in implementing open market operations, "a degtee of caution should be exercised to avoid an impression that a further change in the discount rate was sought over the pe riod immediately ahead." 39

\section{May Meeting}

The acceleration in the growth of M1 continued, and the appropriateness of using that aggregate as a guide to policy was prominent in the discussion at the Committee's meeting on May 20. As of early May, M1 was well above the 8 percent upper limit of its target range for 1986. Some members noted that the relatively rapid growth of $\mathrm{M} 1$ balances needed to be accommodated in light of the continuing adjustments to earlier declines in inflationary expectations and interest rates and some indications of weakness in the economy. ${ }^{\text {a }}$

Other members suggested that the rapid money growth might represent excessive growth in liquidity that eventually would have inflationary consequences. In this view, rapidly growing cash balances "were available to support a considerable pickup in spend-

selbid.

3abid., p. 483.

40 The Commerce Department's preliminary estimate of real GNP growth in the first quarter was 3.7 percent, but industrial production declined on balance over the three months ending in April. Moreover, weakness among oil producers and uncertain but potentially adverse changes in the tax code were retarding business fixed investment. ing at some point in the future." The growth of the broader aggregates had been well within their respective target ranges for 1986, however", which "raised questions as to whether the growth of $\mathrm{M} 1$ really represented a potentially excessive buildup in liquidity or was more of a shift in the composition of liquid holdings in response to relative movements in interest rates." $4 z$ The members generally agreed that some slowing in M1 growth was likely in the weeks ahead. but, because of uncertainties about the timing and extent of the slowdown, "some proposed omitting numerical references in the directive to the Committee's expectations for monetary growth in the second quarter." 43 This proposal was rejected by the majority.

While some evidence of slower real growth had emerged by the time of the May meeting, a number of factors pointed toward more rapid growth later in the year. These factors included rapid money growth, higher prices of finaricial assets, lower energy prices and further depreciation of the dollar against the currencies of major trading partners. In response to these elements in the outlook, "most of the members indicated that they were in favor of continuing to direct open market operations at least initially toward maintaining the existing degree of reserve availability." In their discussion of possible intermeeting ad justments, most members emphasized a potential need for restraint in response to signals of a strengthening economy if growth in the monetary aggregates did not slow as anticipated. The directive stated that, under" those circumstances, "somewhat greater reserve restraint would be acceptable," but in the event of slower money growth and sluggish economic activity, "somewhat lesser reserve restraint might be acceptable."

\section{July Meeting}

Some optimism was expressed at the July meeting about the prospects for economic growth over the second half, and the oullook for inflation remained favorable. There was concem, however, about the

\footnotetext{
\$Record (September $\$ 986$ ), p. 648 .

42.bid., p. 649 .

43bid., p. 650 .

4 abid. p. 650 .

45 bid. pp. $651-52$. In response to rapid growth in required reserves and currency in circulation, the limit on changes in System Account holdings of U.S. government and tederal agency securities between Committee meetings was temporarily ralsed by the Commities trom $\$ 3$ bittion to $\$ 9$ bitlion on June 18 .
} 
sluggish pace of business investment, the lack of improvement in the trade balance, and the "sharp contrasts in the economic performance of different sectors and regions of the country and ... strains on financial institutions that serviced the depressed industries." 46

At the previous meeting, the members had anticipated that a move toward restraint might be necessary. By July, the favorable inflation outlook and concern over slow economic growth led most of the members to believe "that some easing was desirable, which they preferted to implement "at least initially, through a lower discount rate rather than through open market operations." ${ }^{4 z}$ The members accepted a directive "that called for some decrease in the existing degree of reserve pressure, recognizing that relaxation could be accomplished in the first instance by a reduction in the discount rate."

The Committee continued to anticipate a slowdown in the growth of M1, which had decelerated somewhat in June but was still quite rapid (see chart 1). Considerable doubt remained about the extent and timing of such a slowdown, however. With the growth of the broader aggregates around the midpoints of their ranges for the year, and in the context of an unexpectedly sluggish economy, the Committee members agreed that rigid adherence to the original M1 target was inconsistent with their objectives. Because of their uncertainty about the usefulness of M1 as a guide to policy under prevailing conditions, "a majority of the members expressed a preference for not indicating a specific rate of expected growth for M1 in the short-run operational paragraph of the Committee's directive." 49

\section{August Meeting}

The rapid growth of M1 continued through July and into early August. The broader aggregates also grew

\footnotetext{
46Record (October 1986), p. 707.

471bid., p.710. Of course, a cut in the discount rate should increase the demand for borrowed reserves by depository institutions. Under the borrowed reserve operating procedure currently used by the openmarket desk, this would result in open-markel purchases of securities unless the borrowed reserves target is increased. See Gilbert (1985) for a discussion of the current operating procedure and two others that have been used by the open-market desk since 1970. The borrowed reserves targets used by the desk during each yeat are published during the following year in the Federal Reserve Bank of New York Quarterty Review.

${ }^{49}$ Record (October 1986), p. 710. On July 10, the Federal Reserve announced a $1 / 2$-point reduction in the discount rate to 6 percent. 48/bid.
}

quite rapidly, leaving them near the upper limits of their target ranges. At the Committee's August meeting, there was some concern about whether the rapid growth in all three aggregates had inflationary implications. Moreover, there had been further depreciation in the foreign exchange value of the dollar during the intermeeting period. The cheaper dollar was ex pected to put some upward pressure on prices, even though there were not yet any signs of the longawaited reduction in the trade deficit. There was some evidence that economic growth was accelerating from the weak pace of the second quarter, including strong consumption demand and housing activity. Nevertheless, the data reviewed at this meeting continued to indicate a lack of balance in terms of growth among different sectors of the economy and only moderate wage and price pressures. In view of the fact that interest rates had resumed their decline since early June, the members agreed that money growth had not been excessive.

The members considered a number of uncertainties that continued to cloud the economic outlook in August. These included downside risks related to the effects of tax reform legislation, rising consumer debt burdens and sluggish growth of the economies of several major U.S. trading partners. There was also uncertainty about the course of the federal budget deficit and its impact on the economy.

The Committee agreed that "some slight easing in the degree of reserve pressure" was appropriate, and once again stated that this "might be accomplished through a reduction in the discount rate." "The members felt that an intermeeting adjustment in either the direction of ease or restraint might be wartanted, depending on ensuing developments. It was noted, however, that in the event of a further cut in the discount rate, a significant depreciation of the dollar on foreign exchange markets would call for "a little greater caution in the provision of reserves through open market operations. ..."5z The Board reduced the discount rate by $x / 2$ percentage point to $5^{x / 2}$ percent effective August 21.

\section{September Meeting}

Short-term interest rates fell somewhat after the reduction in the discount rate, but longmterm rates

\footnotetext{
50The prelirminary estimate of real GNP growth in H/1986 was 1.1 percent.

51Record (November 1986), p. 785.

salbid.
} 
rose sharply, and by the time of the Committee's meeting on September 23 , the value of the dollar on foreign exchange markets had changed little. The growth rates of M2 and M3 decelerated in August but were still fairly rapid, and M1 growth accelerated from its already rapid pace before slowing sharply in early September.

Most Committee members believed that, despite an apparently stronger economy in the third quarter, an improvement in the trade balance was critical to sustained growth. At the same time, the members felt that there were compelling reasons for expecting some upward price pressures in the quarters ahead, including the likelihood of price increases for imports and import-competing goods stemming from the decline of the dollar, and a continuing reversal of the earlier decline in world oil prices. In addition, there had been indications of a resurgence of inflationary expectations in financial markets and in markets for precious metals. Because "monetay policy had moved toward an increasingly accommodative posture over the course of recent months," several members believed "that it was now time to pause and observe developments..." the current degree of pressure on reserve positions." ${ }^{44}$ In fact, while not ruling out the possibility of a move toward ease, most of the members believed that any potential intermeeting adjustment would more likely involve some restraint, depending on the behavior of a number of guides reflecting economic and financial conditions.

\section{November Meeting}

The Committee's expectation that money growth would fall somewhat from its exceptionally rapid pace during the summer months was fulflled in September and October: $\mathrm{M} 2$ and $\mathrm{M} 3$ advanced at annual rates of 9.3 and 8 percent over the two months, and $\mathrm{M} 1$ growth slowed to a rate of 12.5 percent. Meanwhile, economic activity appeared to be growing at a moderate rate. ${ }^{.5}$

At the Committee's November meeting, the members saw a continuation in the moderate pace of economic expansion as a likely outcome, but certain aspects of the outlook were disturbing. Improvement

\footnotetext{
sarecord (January 1987), p. 34.

${ }^{54}$ lbid., p. 35.

${ }^{55}$ Real GNP grew at an annual rate of 2.4 percent in $1 / 1 / 4986$, according to the preliminary estimate, after growth of only 0.6 percent in II/1986.

${ }^{56}$ Record (February 1987), p. 120.
}

in the trade balance remained elusive and, in large part, dependent upon stronger economic growth overseas to spur demands for U.S. exports. One member referred to increasing protectionist sentiment as a threat to real growth and price stability. In addition, tax reform legislation appeared to be deterring business investment, particularly in structures.

The Committee expected inflation to accelerate somewhat over the quarters ahead because of the lagged impacts of the dollar's depreciation and energy price developments. On the other hand, felatively low rates of capacity utilization in most industries, moderate wage growth and continuing efforts by businesses to reduce costs and improve productivity were factors that would help to hold inflation in check. Moreover, the value of the dollar on foreign exchange markets had stabilized during the intermeeting period. If continued, that stablity would limit a potential source of upward price pressure.

Given the prospects for sustained, moderate growth in economic activity and recent moderation in the growth of the monetary aggregates, the Committee voted for "maintaining unchanged conditions of reserve availability." With regard to possible intermeeting adjustments, some members felt that an easing might be desirable in the context of indications of weakness in the economy, while others felt that money growth below the Committee's expectations should be tolerated in the absence of rising interest rates or a weak economy. The directive did not incorporate any presumption, however, about the likely direction of any intermeeting adjustment in policy.

\section{December Meeting}

The data reviewed at the Committee's December meeting showed that employment growth, industrial production and consumer spending had strengthened in recent months. Sluggishness in business spending and the housing sector were elements of concern, however, and the balance of trade showed no convincing signs of improvement. To a considerable extent, the discussion focused on downside risks to economic growth, particularly for the early part of 1987. The earlier decline of the dollar had enhanced the international competitiveness of many U.S. firms,

\footnotetext{
57The Committee approved a temporary increase from $\$ 6$ bilition to $\$ 7$ billion in the fimit on changes in System Account holdings of govern ment securities during the next intemeeting period, effective December 3 . Ouiright purchases through December 1 had left insufficient leeway for additiona! purchases that woutd be necessary to provide for seasonal increases in required reserves and currency in circulation.
} 
but a number of members expected only ninor improvement in foreign trade over the quarters ahead. The growth of consumer debt was viewed as a factor that might inhibit domestic demand in 1987. More over, consumers and businesses were thought to have shifted some purchases originally planned for 1987 into 1986 to take advantage of certain provisions of the tax code that were scheduled for rescission under the new tax legistation. While the reduction in personal tax rates for 1987 was good news for consumer's, the new tax code along with high vacancy rates had negative implications for spending on multamily housing and nonresidential construction.

In their discussion of policy implementation, the members noted that the broader monetary aggregates, whose growth had slowed in November, were within their target ranges for the vear. On the other hand, the growth of M1 had accelemated in November. Some members felt that a contintation of the rapid growth of that aggregate, and the reserves needed to support it carried an inflationary risk. There was a strong likelihood, however, that M1 velocity would continue to decline even with some slowing in $M 1$ growth. Once again, the Committee agreed that the growth of Mt would be appraised in the context of the growth of the broader aggregates and other developments.

Given the economic outlook and the fact that $\mathrm{M} 2$ and $\mathrm{M} 3$ were within their long-run ranges, the Committee directed the desk "to maintain the existing degree of pressure on reserve positions." "In light of the downside risks to the economy, several members emphasized that in subsequent weeks, developments might call for some easing of reserve conditions. These members noted that pexibily in the direction of ease was afforded by the recent fiming of the dollar's value. Members recognized, however, that circumstances might call for a small adjustment in either direction.

The Committee's deemphasis of M1 as an interme diate target and guide for policy was underscored at the December meeting. A tentative range of 3 to 8 percent for M1 growth in 1987 had been reported to Congress in July as more fentative than usual. In December, a majority of the Commitre indicated that they opposed "establishing a formal target range for M 1 growth in 1987." Many of those members believed, however, that M1 grotwh" should continue to be monitored or evaluated in light of infomation about the economy, prices, and the broad monetary aggregates and other francial variables."

58See Tax Reiorm Act of 1986.

seRecord (April 1987), p. 304.

\section{CONCLUSION}

The FOMC deemphasized M1 and placed relatively more weight on the broader monetary aggregates and various economic and financial indicators in establishing its overall approach to policy and in guiding short-run policy implementation during 1986. A statement typical of the 1986 directives issued by the Committee was that changes in the direction of policy implementation would depend "on the behavior of the aggregates, taking into account the strength of the business expansion, developments in foreign exchange markets, progress against inflation, and conditions in domestic and intemational credit markets." The lengthy ist of factors guiding policy underscored the Committee's desire to take a flexible approach in providing reserves in what it viewed as a highly uncertain economic environment.

The recent changes in the relative weights attached to various policy guides have reflected the Committee's evaluation of the importance and reliability of these variables in influencing real growth and infation. The accommodative thrust of policy was motivated by sluggish economic growth and a number of risks to sustained expansion. While the Committee was wary of inflationary risks in the outlook, price pressures over the course of 1986 were well. contained. Whether monetary policy can continue to provide sufficient liquidity to sustain economic growh without an acceleration in the rate of inflation is a major issue confronting the Federal Reserve in 1987.

\section{REFERENCES}

Broaddus, Alfzed, and Marvin Goodiriend. "Base Drift and the Longer-Run Growth of M1: Experience from a Decade of Monetary Targeting:" Federal Reserve Bank of Richmond Economic Review (November/December 1984), pp. 3-14.

Gibart, R. Atton. "Operating Procedures for Conducting Monetary Policy," this Review (Febriary 1985), pp. 13-21.

"Requiem for Regulation $Q$ : What it Did and Why it Passed Away," this Feview (February 1986), pp. 22-37.

Hater, R. W. "Much Ado About M2," this Review (October 1981), pp. $13-18$.

"The FOMG in 1985: Reacting to Declining M1 Velocity." this Review (February 1986), pp. 5-21.

Keeley, Michael $C_{0}$, and Gary C. Zimmerman. "Deposit Pate Dereg. ulation and the Demand for Transactions Media," Federal Reserve Bank of San Francisco Economic Roview (Summer 1986), pp. 4762.

Lawier, Parick J. "The Large Monotary Aggregates as Intermediate

\footnotetext{
wibid., p. 302

6r Pecond (February 1987 ), p. 122.
} 
Policy Targets," Voice of the Federal Reserve Bank of Dallas (November 1981), pp. 1-13.

Mann, Catherine L. "Prices, Profit Margins, and Exchange Rates," Federal Reserve Bulletin (June 1986), pp. 366-79.

Mehra, Yash. "The Recent Financial Deregulation and the Interest Elasticity of the Simple M1 Demand Function: An Empirtcal Note:" Federal Reserve Bank of Richmond, Working Paper No. 85-3 (1985).

Roth, Howard. "Effects of Financial Deregutation on Monetary Policy." Federal Reserve Bank of Kansas City Economic Review (March 1985), pp. 17-29.
Tax Reform Act of 1986. H. Rept. 99.841, 99 Cong. 2 Sess. (GPO, 1986)

Volcker, Paul A. Statement before the Committee on Banking, Housing, and Urban Affairs, U.S. Senate, Juty 23, 1986, Federal Reserve Bulletin (September 1986), pp. 635-42.

Walsh, Carl E. "In Defense of Base Drift" American Economic Review (September 1986), pp. 692-700.

Wenninger, John. "Responsiveness of Interest Rate Spreads and Deposit Flows to Changes in Market Rates," Federal Reserve Bank of New York Quarterly Review (Autumn 1986), pp. 1-10. 